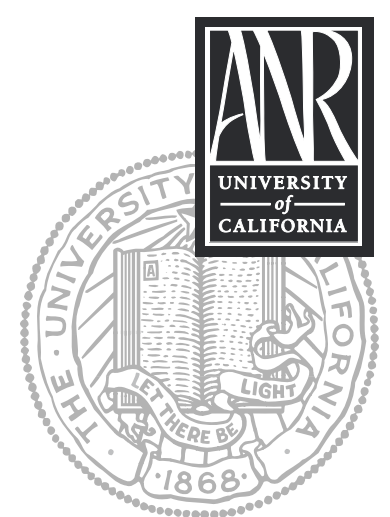

UNIVERSITY OF CALIFORNIA

Division of Agriculture and Natural Resources http://anrcatalog.ucdavis.edu

\title{
FOREST STEWARDSHIP SERIES 22 Forest Taxation, Estate Planning, and Conservation Easements
}

CLARALYNN NUNAMAKER, California Registered Professional Forester, Scotland, UK; KIMBERLY RODRIGUES, Regional Director, UC Agriculture and Natural Resources North Coast and Mountain Region; JOHN LEBLANC, California Registered Professional Forester, Garden Valley, CA; GARY NAKAMURA, UCCE Forestry Specialist, Department of Environmental Science, Policy, and Management, University of California, Berkeley

Every owner of forestland should understand the different taxes that apply to forest ownership and forestry operations, including state and federal income taxes, property tax, and yield taxes (tax applied at the time of harvesting timber).

If you want to minimize your taxes, and you are willing to spend

\section{Objective}

Understand the variety and intent of taxation by federal, state, and local government as applied to forest properties.

\section{Competencies}

- Understand the three main types of taxation: income, timber yield, and property.

- Become familiar with the basic principles of recordkeeping as related to forest taxation.

- Understand strategies for minimizing the taxes on forest properties and income.

\section{Related Forest Stewardship} Series Publications

- Professional Assistance, ANR Publication 8254

- Stewardship Objectives and Planning, ANR Publication 8248 some time learning about tax law, doing some bookkeeping, and possibly hiring a qualified accountant to help out, the suggestions in this publication will likely apply to you. However, situations vary, and you should consult with a tax professional for specific advice. Enrolled agents (EA) are specialists in federal taxes, although not all are acquainted with forestry issues; they can be found in telephone directories under "Taxes: Consultants and Advisors."

\section{INCOME TAXATION}

Taxation of income derived from forestry investments is a complex topic at both the federal and state levels. Tax laws, regulations, and guidelines are many, detailed, and technical. Tax legislation is subject to frequent change and judicial interpretation. This discussion is intended only as an introduction to a number of taxation concepts related to forestland in the state of California. The landowner is well advised to seek the advice of a professional tax consultant familiar with timber taxation.

Income taxes on timber revenues are complicated, especially in regards to capital gains treatment. Since income taxation was established in 1913, timber assets have gone from almost no treatment as capital gains to nearly full treatment. Recent legislation has further confused the issue.

For individuals, California state income taxes are generally similar to federal income taxes. However, some important differences are pointed out in the following discussion, and other differences may apply to your particular situation. Check the resources listed at the end of this publication and consult a professional tax consultant.

\section{Capital Gains}

Since timber is a long-term investment, it is a capital asset subject to capital gains treatment in income taxation. Capital gain is the difference between the selling price of a capital asset and its original cost, or basis. A capital asset is property held by the taxpayer. Capital loss occurs when the cost of an asset is greater than its selling price. 
The conditions under which forestry investments and income and loss are considered capital or ordinary are discussed later in this section.

A major difference between capital gain and ordinary income is the manner in which costs can be deducted from income. With ordinary income, costs are expensed, that is, deducted from income in the year that the cost is incurred. In contrast, capital expenditures, costs that give rise to capital assets, are considered an exchange of one capital asset (cash) for another (property). Thus, no outflow of assets occurs. Capital expenditures or costs cannot be deducted from ordinary income in the year that they occur. Capital expenditures are recovered for tax purposes when the capital asset is sold or timber is harvested. Expenditures are then deducted from the capital gains. Considering the time value of money, it is generally best to deduct costs from ordinary income in the year they occur. Expenditures are not increased to reflect inflation, that is, a \$100 expense in 1950 is still just $\$ 100$ in 2007 when the harvest occurs and capital gains are realized.

The advantage to capital gains treatment is that mid-term and long-term capital gain income is taxed at lower rates than ordinary income. Capital gains reported before 1987 are exempt from taxation. Capital gains income is not taxable for Social Security purposes as ordinary income. For retired people receiving Social Security benefits, when earned income exceeds certain levels, part of the Social Security benefits must be paid back. Capital gains income is not considered earned income in this calculation.

Another difference between capital gains and ordinary income is the treatment of losses. Capital loss occurs when the original cost (or basis) is higher than the selling price. A capital loss is first deducted from the capital gains of other transactions. Any remaining loss is deducted from other income, but not more than $\$ 3,000$ can be deducted in any tax year.

A difficulty in assigning capital gains treatment to timber is that the product is essentially the factory that produces the product. This discussion summarizes considerations important to owners of nonindustrial private forestland.

Timber for capital gains purposes includes standing trees used for wood products. It also includes Christmas trees older than 6 years of age from seed. Timber does not include logs already cut, tops, limbs, stumps, chips, seedlings grown for transplanting, or live trees used for ornamental purposes.

The timber must be held for a period of 18 months or longer (as measured from the date of acquisition to the date of disposal) to be eligible for long-term capital gains treatment. For landowners who purchase their property as an investment, infrequent lump sum sales of timber are allowed capital gains treatment. In a lump sum sale, payment is made for the standing timber as a whole unit and not on a per unit cut basis. Payment is usually made before the timber is cut. These sales must be discontinuous and isolated. If the taxpayer makes a substantial effort to promote the sale, capital gains treatment might be denied. This type of sale is generally for owners who are not managing their property for timber.

Section $631 \mathrm{~b}$ of the Internal Revenue Code (IRC) is of special interest to forest landowners who actively manage their forest as a business. This section affords capital gains treatment to the taxpayer who retains an economic interest in the timber. The seller must retain legal title to the timber until it is cut. The date of cutting is when the volume of the timber is first accurately determined. The seller must be paid on a per unit cut basis. When selling timber on the stump, your contract must state that you retain title to the timber until it is scaled and that you are paid on a per unit basis. A well-written contract is essential to demonstrate a retained economic interest in the timber. 


\section{Depletion Allowance}

As timber is cut, the original capital investment, the basis of the timber, is reduced or depleted. Because the trees are rarely all cut at the same time, the original cost must be modified to give the adjusted basis. The adjusted basis is the original purchase price of the timber adjusted for addition or deletion of the capital of the property. The depletion allowance is deducted from timber sale receipts in calculating taxable income. In this way the original investment in timber is recovered. Depletion is calculated the same for California income tax as it is for federal income taxes.

To use the depletion allowance, the cost basis of the timber must be established. The cost basis is the fair market value of the timber at the time of acquisition. The cost of land and improvements are carried in a separate account. At the time of purchase or inheritance, the fair market value of the property is allocated between the timber and the land. These amounts can be estimated well after original acquisition. However, there is a cost in making such determinations. For most landowners, if the property was acquired more than 10 years ago, the basis may have been so small that the cost of calculating that original basis may exceed the tax savings. The more recent the purchase, the greater the justification of the expense to calculate the basis.

If more timberland is purchased, the original basis must be updated. Remember to allocate between the land and the timber. As timber is cut, the basis must be depleted to reflect the amount removed. The depletion unit is defined as: depletion unit ( $\$ / M B F)$ $=$ total adjusted basis (timber value) $\div$ total timber volume, where $\mathrm{MBF}=$ thousand board feet.

The depletion allowance is determined by multiplying the volume of timber removed by the depletion unit. The basis is then adjusted by subtracting the depletion allowance from the previous adjusted basis. Land and timber translations relating to these sections of the IRC ( $\$ \S 1221,1231,631$ a, and 631b) are documented on IRS Form T, Forest Industries Tax Schedules.

\section{Record Keeping}

Up-to-date records must be kept to accurately assess tax liability and take advantage of tax reduction provisions. Good records are also necessary to take advantage of cost share programs. A written management plan is a useful tool to establish these records.

Two basic accounting methods may be used: accrual accounting or cash accounting. With the accrual method, transactions are recorded as they occur. The date of payment is not considered. Transactions under cash accounting are recorded when cash is received or paid out. Either system may be used. For the small landowner, cash accounting is often the easiest. The accounting system consists of a transaction journal and a series of ledgers documenting various accounts and subaccounts. The transaction journal is a chronological listing of all transactions regarding the property. Each transaction is given a number, which is used to key to the various ledgers. The date, description, amount, intent, and other pertinent details are given. Other financial information, such as the results of a timber cruise, can be included.

Ledgers documenting the various accounts should be maintained. At a minimum, accounts should be established for land, timber, buildings, improvements, and Christmas trees, if appropriate. Subaccounts are established in some of these to give a more specific representation.

The timber account is usually divided into subaccounts for plantation, submerchantable timber, and timber. The plantation subaccount documents the costs of site preparation, seedlings, planting, planting tools, and some costs of releasing the plantation. As the seedlings reach the sapling stage, the plantation subaccount is closed and amounts are transferred to the submerchantable timber subaccount. Likewise, when 
the timber becomes merchantable, it is transferred to the merchantable timber subaccount. For mature timber, both cost and volume data should be kept.

A similar series of accounts are kept for Christmas trees. Because they become merchantable faster than most other forest products, special rules apply.

Land, building, equipment, roads, and other assets should have a separate account. In short, any asset on which depreciation is taken or that may affect the adjustment of the basis should be included in the accounting system.

\section{Expenses}

Expenses may be capital, ordinary, or carrying charges. Capital expenses are related to obtaining or improving a capital asset. They are not deductible in the year they are incurred but are recovered when the capital asset is sold, that is, when timber is harvested. The expenses of a sale are costs that must be charged against capital gains.

Ordinary or current expenditures are deducted from income in the year they occur. Because of the time value of money, it is usually advantageous to write off costs as short-term expenses whenever possible, that is, deducting expenses from current income reduces taxes more than deducting those expenses from future capital gain because $\$ 100$ in current expenses will be just $\$ 100$ when the timber is harvested 50 years in the future. There is no increase in costs due to inflation. Whether expenses are capital or ordinary is frequently debated.

Carrying charges are ordinary expenses that may be capitalized at the election of the taxpayer. These costs are deductible, but in some situations, ordinary expensessuch as interest on mortgage, fire protection costs, or insurance-may be treated as capital expenses. Taxpayers who take a loss for the year and have no income to deduct expenses from or who take the standard deduction instead of itemizing deductions may benefit from capitalizing these expenses. Some taxes are deductible as ordinary expenses if itemized on your federal return. These include state and local taxes for real and personal property and income taxes. Federal income, excise, gift, inheritance, or estate taxes are not deductible.

Most of the costs of reforestation are considered capital expenses in that they produce a capital asset. These costs should be included in the basis for depletion. Brush removal within 2 years of planting is considered a cost of reforestation and should be capitalized.

Because reforestation is considered a capital expense, it has generally been a disincentive to small landowners to invest in their land due to the long holding period before these capital expenses can be deducted from capital gains income. In 1980, to encourage reforestation, Congress passed PL 96-451, allowing a 10 percent tax credit for planting and reforestation expenses to a maximum of $\$ 10,000$ per year. Cost-share assistance receipts cannot be included in the total. In addition to the 10 percent tax credit, certain eligible expenses may be amortized over 7 years.

California tax law differs from federal tax law for reforestation expenses. Certain expenses may be amortized over 60 months ( 5 years), instead of 96 months ( 8 years). Election to amortize is decided by the taxpayer but must continue until fully amortized.

The costs of timber cruises (an inventory of trees or timber) are deductible from ordinary income when the expenses are incurred for management purposes, such as developing a management plan. Timber cruises for the purpose of establishing a timber sale volume are a cost of the sale and are deducted from sale proceeds when the sale occurs.

Costs for temporary logging roads that are used for one operation and then abandoned are depreciated over the period of use. Permanent roads have various costs that are treated separately. Costs of establishing the road, such as surveying, clearing the 


\section{Reforestation Tax Credit}

The following example illustrates the procedure used to calculate the reforestation tax credit.

Assume a small landowner has $\$ 12,000$ in eligible reforestation expenses, of which 75 percent is covered by cost-share programs. Under the current law, 10 percent of the amount, exclusive of the cost-shared amount, is eligible for the reforestation tax credit. The reforestation tax credit amount $=\$ 12,000-(0.75 \times \$ 12,000)$ (the cost-share grant amount) $=\$ 12,000$ - $\$ 9,000$, or $\$ 3,000$. The landowner can take a 10 percent tax credit on the $\$ 3,000$ invested: $\$ 3,000 \times 0.10=$ $\$ 300$. This is a tax credit that reduces your tax liability, not a deduction from income.

In addition, the full $\$ 3,000$ can be amortized over a 7-year period. Because the investment is assumed to occur in mid-year, only one-fourteenth may be deducted in years 1 and 8 . In years 2 to 7 the landowner deducts one-seventh of the investment. This deduction for the $\$ 3,000$ investment is calculated as follows: Years 1 and $8: \$ 3,000 \div 14=\$ 214.28$; Years 2 through $7: \$ 3,000 \div 7=\$ 428.57$. roadbed, or other nonrecurring costs, are capital investments used to adjust the basis. Costs for culvert repair, bridges, or other periodic events are depreciable as a capital expense. Annual maintenance costs, such as graveling, repairing water bars, and mowing roadsides, are deductible expenses from ordinary income.

Casualty losses resulting from sudden, unanticipated natural disasters may be deducted from ordinary income. Fire losses are the most common example. In contrast, losses due to insect attack usually must be capitalized. These types of losses are considered capital losses because they can be anticipated and lessened by planning and preemptive actions such as thinning and competition control. It helps to have a good inventory of your timber and other values when claiming these losses. It can be difficult and expensive to recreate conditions and values before the fire or disaster after the fact.

\section{Active, Passive, and Portfolio Activities}

Three types of income or loss are recognized: active, portfolio, and passive. Active income includes salary, bonuses, and other income derived from for-profit activities in which the taxpayer materially participates. Portfolio income is derived from investments and includes interest, dividends, and royalties, unless earned in the ordinary course of a trade or business. Passive income or loss is derived from limited partnerships and other business, trade, or investment activities in which the taxpayer does not materially participate.

Losses from passive activities can offset only passive income. They cannot be deducted from active or portfolio income. Passive losses can be carried over to future years and applied against future passive income. Tax credits from passive activities, such as the reforestation tax credit, can offset only the tax payable on passive income. The basis in property is reduced by depreciation even if the deductions are not usable because of passive loss rules.

Most taxpayer losses from real estate operations are considered passive, even if the taxpayer is materially participating. If the taxpayer has at least a 10 percent interest in the venture, up to $\$ 25,000$ of losses may be considered nonpassive and, therefore, deductible.

The use of consultants should not make an activity passive if the consultant, such as a forester, acts at the request of the taxpayer rather than as a paid advisor directing the conduct of the taxpayer. This means that the taxpayer must make the actual decisions; however, the forester can make suggestions and recommendations.

\section{Other Income Tax Laws Affecting Landowners}

If an activity makes a profit in less than 3 out of the past 5 years, the IRS assumes that the activity is a hobby and not a profit-making activity, that is, not a business subject to business expense and tax treatment. All such assumptions by the IRS may be contested, usually successfully. A written management plan demonstrates the long-term nature of forestry investments and the landowner's objective of a profit-making activity.

Tax laws are complex and subject to interpretation by the taxpayer, courts, and the IRS. If your tax situation is complicated, consult with a professional tax consultant or certified public account who is familiar with tax treatment of timber. Many are not. Conversely, foresters who are technically proficient in their field may be unfamiliar with tax laws. Some foresters do specialize in tax preparation. 
All professionals charge for their time, usually by the hour. Keeping your records clear and organized may save a significant amount of money in tax preparation costs. Current knowledge of tax legislation and regulations, including recent changes, may allow you to minimize tax liability within the law's constraints. Joining landowner associations is one means of keeping current.

\section{PROPERTY TAXATION}

The traditional means of revenue generation for local governments in California has been the collection of an annual ad valorem property tax, that is, an annual tax based on the current assessed value of property at its highest and best use. On forest property, where annual taxes must be paid out of infrequent income from timber sales, annual ad valorem taxes have been a disincentive to sustainable forest management for small landowners. The ad valorem tax has often been seen as an incentive for converting the land to its defined "highest and best use," which is usually the conversion of open space forest to subdivision and homes. Changes in California property tax laws were enacted in 1976 to alleviate these problems.

In 1976, the state Forest Taxation Reform Act established a timber yield tax and the timberland preserve zone, later renamed timberland production zone (TPZ), to emphasize the timber production and working forest intent of the legislation. The annual ad valorem property tax on standing timber value was changed to a yield tax on harvested timber.

\section{Timberland Production Zone}

A timberland production zone (TPZ) is a county zoning classification in which the primary allowed use is the production of timber. Annual property tax is paid, but the assessed value of TPZ land is based on its value for growing timber, not its development value for homes. This usually results in a lower tax assessment than customary "highest and best use" valuation. In return for the lower assessment, the property must be managed for timber and compatible uses for a minimum of 10 more years.

TPZ property valuation is determined in a joint process between the county assessor and the State Board of Equalization. TPZ land is put into five productivity classes by the county assessor corresponding to timber site class (Sites I to V) as determined from soil and vegetation surveys or other sources. The State Board of Equalization prepares timberland value tables based on these productivity classes. These tables show the bare land value for TPZ land. The assessor can add to these values for existing compatible uses such as grazing value per acre.

There are two ways to obtain TPZ zoning if it is not currently applied to a property. Under the first procedure, the landowner petitions the county to classify the land as TPZ. The land must be capable of growing and harvesting timber, and it must meet the following criteria.

- A forest management plan prepared or approved by a registered professional forester (RPF) must be submitted. Timber harvest must be provided for in a reasonable time.

- The parcel must meet stocking requirements set forth in the forest practice rules adopted by the State Board of Forestry for the district in which the parcel is located. Alternatively, the landowner can make an agreement with the county that stocking requirements will be met within 5 years.

- At the county's option, two additional requirements may have to be met. These are a minimum contiguous ownership of up to 160 acres (some counties elect to make this contiguous ownership smaller) and that the land must be Site III or better. 
The second way is that timberland may be added to an existing TPZ parcel if the landowner already has TPZ land contiguous to the new property. Some counties require physical contiguity, while others require the addition to be managed jointly, without physical proximity.

You may be able to remove property from TPZ by either of two processes. The first is to petition the county board of supervisors for rezoning. This method faces some constraints. The county does not have to approve the rezoning. Also, rezoning is not effective until 10 years after the date of approval. Finally, property taxes increase immediately and continue to increase annually over the ensuing 10 years.

Immediate rezoning allows for a new land use upon approval. Immediate rezoning requires that a public meeting be held to show that rezoning is in the public interest. An environmental impact report (EIR) may be required at the landowner's expense. A conversion permit from the State Board of Forestry must be obtained. Immediate rezoning requires you to pay taxes on the full cash value of the property in its new use for the current year and for the number of years, up to 10, that the property has been in TPZ.

The purpose of the rezoning and immediate rezoning restrictions is to ensure that TPZ valuation is not used simply as a tax shelter. TPZ landowners wishing to convert their land to another use have a mechanism to do so, but that mechanism may be costly.

\section{YIELD TAXATION}

Under the current yield tax system, a tax is paid on the value of the timber just before it is harvested. This is the stumpage value, the value of the tree standing on the stump. The owner of the timber at the time it is cut is responsible for paying the tax. Often the Licensed Timber Operator (LTO, or logger) who harvests the timber arranges for this tax to be paid.

Taxpayers use the current Harvest Value Schedule to compute the yield tax. Every six months, the State Board of Equalization, Timber Tax Division, publishes the Harvest Value Schedules that show average timber prices for geographical areas called timber value areas (TVAs) (for a map showing the boundaries of the timber value areas, see figure 1 . The map is also available at the BOE Web site, http://www.boe.ca.gov/proptaxes/pdf/20071HFinal.pdf). TVAs generally have uniform prices for timber throughout. The actual price you receive for your timber will probably vary from the schedule values, which are the previous six-months' average of many sales. However, the tax you pay is based on the schedule values, not your actual sales prices. Harvest value schedules are posted at the BOE Web site given above.

To calculate the tax, locate the TVA for your property and note the species, quantity and quality of the timber harvested along with the type of logging system used. At the bottom of the table are adjustments to harvest value that may apply to your situation. Multiply the volume you harvested by the value reported in the table, and then by the tax rate, which is 2.9 percent. This timber yield tax rate has been very stable at 2.9 percent for more than a decade.

For example, using the January 1 through June 30, 2007, Harvest Value Schedule, Table G, if your harvest is in El Dorado County, your TVA is 8 (TVA8). Assume you harvested $75 \mathrm{MBF}$ of young-growth ponderosa pine using tractor logging. The Harvest Value Schedule lists young-growth ponderosa pine in TVA8 at $\$ 270$ per MBF. However, there is a $\$ 100$ adjustment for a small total volume of less than $100 \mathrm{MBF}$ harvested in that quarter, making your harvest value $\$ 170$ per MBF. Multiply the adjusted harvest value ( $\$ 410$ per $\mathrm{MBF}$ ) by the volume harvested (75 MBF) to get the total harvest value $(\$ 12,750)$. Multiply this by the 2.9 percent tax rate to get a yield tax of $\$ 370$. Note that the Harvest Value Schedule value, not the actual timber revenue, is the basis for determining yield tax payments. 


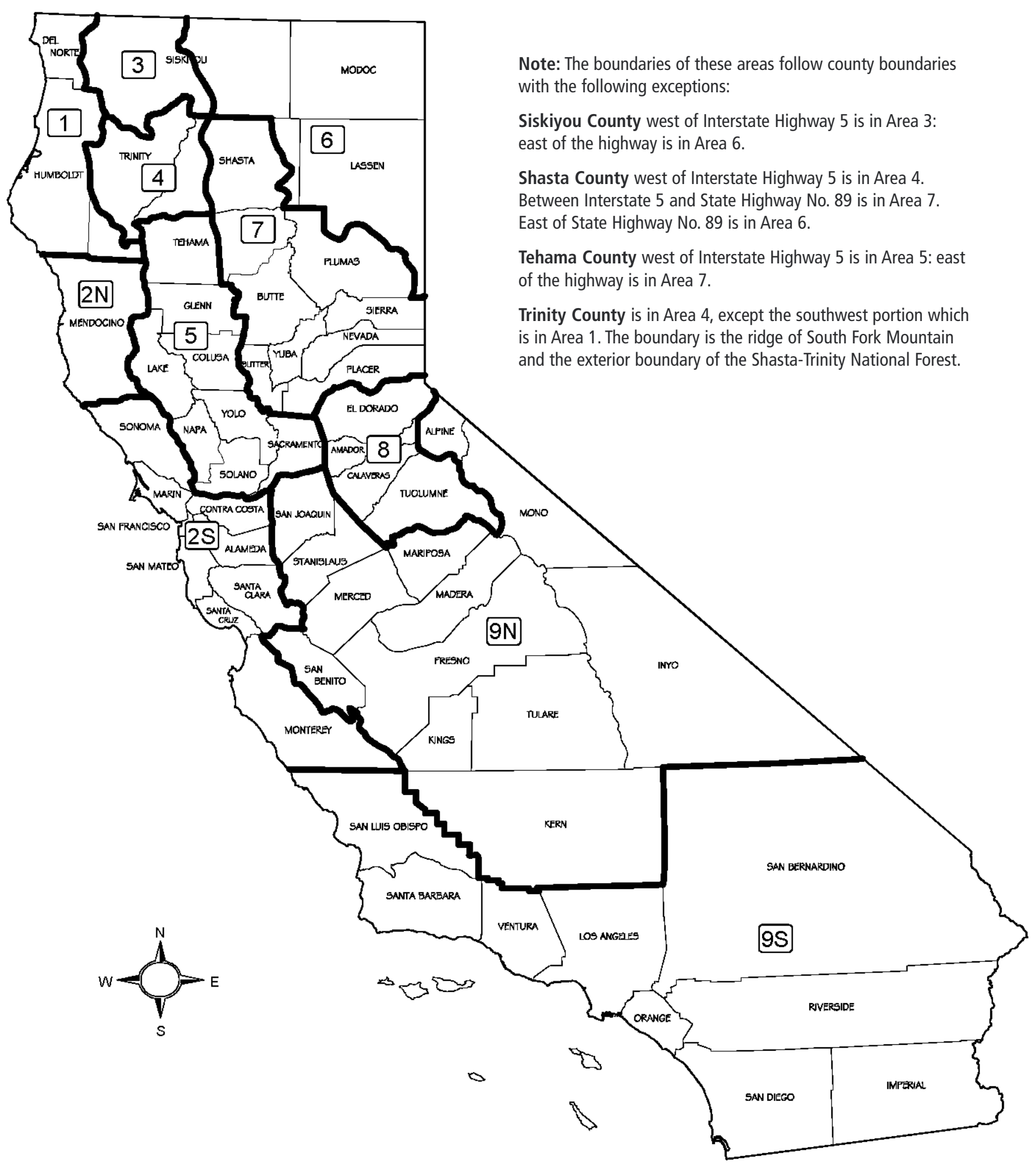

Figure 1. Timber value areas of California. Source: Courtesy California State Board of Equalization.. 


\section{Questions To Ask When Choosing an Estate Planning Lawyer}

Estate planning for forest landowners is unique. Your lawyer must be knowledgeable in this specialized field. The following questions are designed to help you assess the candidate's knowledge of estate planning as it relates to forestland.

Q. How is Form $T$, the Forest Industries Schedules, used to formulate adjusted basis and depletion of timber lands?

A. Schedule F of Form T provides a series of questions that establish depletion or adjusted basis (basis is essentially a calculation of "book value" for the land.)

Q. What is special use valuation and how does it apply to forest ownership?

A Special use valuation is a special provision within the federal tax code that allows an estate to be evaluated by its present use rather than the highest and best use, which is normally used. Under certain circumstances, forest estates can be appraised for timber growing rather than for potential development use, thus reducing the value of the estate and estate tax liability.

Q. Who is the consulting forester you have worked with in other estate planning endeavors?

A. Although the answer may include several foresters, you should expect the lawyer to have a working relationship with a capable and trustworthy forester.

Q. What is a conservation easement?

A. It is an agreement between a landowner and a conservation organization or public agency that restricts the use of the property in perpetuity, to keep the land in forest use.

Q. When a conservation easement is passed to a legal recipient, how many years does one have to use up (carry forward) the value in tax deduction?

A. Five years.

Q. What is a remainder interest?

A. The act of making a gift now to take effect at the time of death.

Q. Under the "general rule," how much may a taxpayer who makes a charitable contribution of property deduct from his or her income?

A. Thirty percent.

Q. Under the "special rule," what provisions apply?

A. Under this rule, a taxpayer who makes a charitable gift of appreciated property can choose to reduce the amount of the deduction to the cost or basis of the property.

Q. Who is Stephen J. Small?

A. He is the author of Preserving Family Lands, a book on estate planning, and the original author of the federal tax law that provides special tax treatment for donated conservation easements.

Other important questions:

Q. How many estate plans have you prepared for nonindustrial private forestland owners?

Q. What is your fee schedule?

Q. How will you determine what my interests and objectives are? (It is important that you choose a lawyer who has your interests and objectives in mind.)

Q. Can you provide three nonindustrial private forestland owner references who have received estate planning services from you? (You should contact the references for recommendations.)

Source: Michael Washburn and Lloyd Casey, Forest Stewardship 13: Estate Planning (University Park: The Pennsylvania State University and the Pennsylvania Forest Stewardship Program, 1997), reprinted with permission.

\section{ESTATE PLANNING}

Federal inheritance taxes apply only if your taxable estate is $\$ 1$ million or more (2007). Inheritance tax laws will be changing in 2010, so visit the National Timber Tax Web site (http://www. timbertax.org/) for updates on this and other taxes.

Good estate planning can save your heirs thousands of dollars and may prevent the selling of parcels or heavy logging to pay estate taxes. This is particularly true in California, where land values are high and many forest landowners are "landrich and cash-poor," which can lead to a crisis for your heirs. However, forest landowners should take a broad view of estate planning and wealth transfer, and not focus solely on minimizing estate taxes unless that is your sole estate goal and interest. Some of the more common estate planning strategies include

- gifting, or taking advantage of tax-free gifts of $\$ 10,000$ per year per person to an unlimited number of recipients

- living trusts, which avoid probate and help reduce taxes

- life insurance and life insurance trusts, which can provide the cash needed to pay the estate tax

- charitable gifts you make to reduce the tax liability of the estate

- family partnerships to remove property from the taxable estate

- conservation easements to help reduce the taxable basis of the estate 
The tax laws are changing, and proposals exist to eliminate estate taxes altogether at some point in the future. Bear in mind, however, that it is wise to plan your estate around the possibility that the tax may not be completely eliminated. The new laws sunset in 2010 and, if not extended by Congress, the current laws would remain in effect.

Estate planning is even more complex than timber taxation. Knowledge of and experience with the estate tax laws is necessary to ensure that your estate is taxed at the minimum legal rate. It is critical to have the assistance of a good estate planning lawyer. To find a good lawyer, ask your forester, other landowners, or members of organizations such as the Forest Landowners of California (www.forestlandowners.org).

The services of a good estate tax lawyer, trust officer, and estate planner may be necessary if your efforts for producing a valuable timber crop on your land are to be continued by your heirs.

Remember that the professionals you employ charge by the hour, and an expert's time is costly. Those charges, though, are frequently money well spent in terms of the amount of taxes assessed. The following questions will assist you in determining your estate and wealth transfer goals, whether or not you hire professional help.

- Who will receive your assets? You must supply the name of your beneficiary and any special considerations, such as if the beneficiary is under age of majority.

- Why are you making your estate plan? What are your objectives?

- When do you want to implement the transfer-during life, at death, or after death?

- What property rights do you wish to transfer and to whom? You should have a reasonable inventory of the assets on your property.

- How, given your objectives, is the property to be transferred? Tax savings are important at this point but only to the extent they do not interfere with your objectives.

Due to the great complexity of estate planning, you are strongly advised to consult a professional in order to ensure that the land that is such an important part of your life continues to benefit your family.

\section{CONSERVATION EASEMENTS}

A conservation easement is a tool for forest landowners to preserve or conserve certain aspects of their property. The easement places restrictions on the use of the property, for example, prohibiting tree clearing for intensive agricultural development or for subdivision. These restrictions can reduce the assessed value of the property and the annual and estate taxes due.

For example, a property worth $\$ 500,000$ before restrictions might be worth only $\$ 100,000$ after an easement is in place that, for example, restricts subdivision and development rights. A very restrictive easement can reduce the assessed value of the land by as much as 90 percent. The $\$ 400,000$ "loss" can be taken as a charitable contribution by the landowner over a 5 -year period to reduce taxable income. It also reduces the value of the taxable estate and can therefore be a useful estate planning tool. In some cases, the landowner may receive payment for the conservation easement. The controls on land use that are imposed in perpetuity are as important as the tax implications of an easement. In this case, the property can never be subdivided and developed and will continue to function as a forest. 


\section{A Landowner's Experience with a Conservation Easement}

Chris Hayes has nothing but positive things to say about conservation easements. It worked for him.

Hayes owns 952 acres of mixed range and forestland that spans the Sonoma-Mendocino county border. He bought the property 12 years ago to use for hunting. It had been logged in the past but his interest was in stewardship activities, including a nonindustrial timber management plan (NTMP) to do forest thinning.

In 1997, Hayes was looking for a tax break and decided to investigate conservation easements. He did a lot of homework, got good professional help, and was able to accomplish his objectives with a conservation easement. He feels that everyone benefited from the transaction. "It's one of those situations where it's beneficial to the landowner and the land both."

This was a learning experience that took a bit of effort. First, Hayes had to find a land trust to take his easement. He also hired an attorney who was knowledgeable about conservation easements to go over the agreement. Since timber was a great deal of the value of the property, he worked with a forester to evaluate the forest resources and give advice on long-term management. And an independent appraiser was needed to calculate the property's total worth.

The costs of securing the conservation easement included payments to all the professionals plus a gift to the land trust for management purposes constitutes a charitable donation. But all those costs are tax deductible, and Hayes feels he got "a good deal."

"It's time consuming. You have to go through a few steps," Hayes acknowledges. The number of steps depends on how big the property is and how complicated the easement is. Hayes was under a time constraint because he wanted the tax break at the end of the year. His easement took 6 months to complete.

A conservation easement devalues the property by restricting certain rights. In this case, the development rights that were ceded were rights Hayes had no intention of exercising anyway. Twenty acres around the house were excluded from the conservation easement in case he wants to "do things" with that area in the future.

"The conservation easement is pretty specific. The land trust maps the whole property and then goes over it on the ground. They have the right to come by to check that the easement terms are being followed, but usually they will notify and let us know they are coming by to check. It hasn't been invasive at all. They've only been up there once in three years. It all depends on the land trust, the nature of the easement, and how easy it is to come by."

Forest management plans are built into a conservation easement. Each one is different, depending on the needs and objectives of the landowner, the land trust, and the property characteristics. Hayes retained the right to log within the NTMP.

"You can give away as much or as little as you want," he notes. "It all depends on how you write up the easement. Basically it's a negotiationas long as you have something the land trust values, you have leverage."

His experience has inspired others. Since Hayes got his conservation easement, his neighbors are following suit.

His advice for others? The most important thing is to make sure you know what you're willing to give up. Get an attorney to look out for your interests.

"For me it was a perfect match. I don't have designs to change the property any more than it's been changed. It hasn't really changed my life or how I use my property."
An easement is held by a conservation organization, such as a land trust, that helps in the planning and writing of the easement. Have a forester look over the easement to make sure you are giving up only those rights you want to give up. Land trusts vary in the types of easements they prefer to handle. Some focus on strict preservation while others support working landscapes where agriculture, cattle grazing, or timber production are permitted with some restrictions.

Because conservation easements are tied to the title of the land and are usually valid in perpetuity, be careful about what rights you give up and pay close attention to the wording. Think about what could possibly happen, not what usually happens, because the easement will apply to all situations. Be sure you understand the fine print, and have your forester or lawyer explain anything you do not understand.

The easement can be tailored to suit your needs and objectives. Below are some examples of rights that you can choose to give up or specifically retain.

- Subdivision, which includes the right to divide parcels or sell off individual parcels from a large holding.

- Development, which might include development for housing, vineyards, or other purposes.

- Timber harvesting. You may choose to prohibit or restrict timber operations. You may agree to or decline restrictions related to harvest timing or frequency, silvicultural systems, and environmental constraints.

Conservation easements are expensive, but if you have an income high enough to take advantage of the charitable contribution tax deduction, they can reduce your income taxes. Costs associated with developing the easement include planning, writing, filing fees, and a donation to 


\section{Conservation Easement Frequently Asked Questions}

Q. What is a conservation easement?

A. A conservation easement is a voluntary agreement with a nonprofit land trust or government agency that allows a landowner to limit the type or amount of development on their property while retaining private ownership of the land. When completed, the conservation easement becomes part of the property deed. A way to visualize this is to think of owning land as a bundle of property rights: - the right to build a house, extract minerals, harvest timber, allow hunting, graze cattle, subdivide the property, and so on. A landowner may give up certain rights through the conservation easement.

\section{Q. How does it work?}

A. Conservation easements are tailored to the needs of the landowner and the recipient organization (which must be a qualified nonprofit organization or government agency). The easement holder agrees to hold, but not use, the transferred rights. A landowner may either donate the conservation easement or sell it for partial or full appraised value. The terms of each conservation easement are negotiated by the landowner and the recipient organization.

\section{Q. Who owns and manages easement protected land?}

A. The landowner retains full rights to control and manage the property within the terms of the easement. The landowner continues to bear all costs and liabilities related to ownership and maintenance of the property. The organization that owns the easement will monitor the property to ensure compliance with the easement's terms, but it has no other management responsibilities and exercises no direct control over other activities on the land.

Q. Why do people grant conservation easements?

A. People grant conservation easements because they want to protect their property from future unwanted development or land uses while retaining ownership of their land. By granting a conservation easement, a landowner can assure that the property will be protected forever, regardless of who owns it in the future. An additional benefit is that the donation of an easement may provide significant financial advantages.

Q. What kind of financial advantages result from donating an easement?

A. Many landowners receive a federal income tax deduction for the gift of a conservation easement, as a charitable donation. The IRS allows a deduction if the easement is perpetual, is donated "exclusively for conservation purposes," and meets certain criteria for those conservation purposes. The amount of the tax deduction is determined by the value of the easement. In addition, the landowner may realize estate and property tax relief because the value of the property is reduced.

Q. What activities are allowed on land protected by an easement?

A. These depend on the landowner's wishes and the terms of the easement. In some cases, no further development is allowed. In others, some additional development is allowed, but the amount and type is restricted. Conservation easements may cover all or a portion of a property, and specific restrictions can vary for different parts. the conservation organization to enforce the easement. The conservation organization is charged with ensuring that the conditions of the easement are followed in perpetuity by the landowners, and the donation is designed to cover the costs of doing so.

\section{SUMMARY}

Tax laws are complex, and most forest landowners will require the assistance of qualified tax professionals if they have relatively active management programs involving timber production. A few general principles can help you and your family.

- Keep accurate, well-organized, detailed records. If you are engaged in timber production, keep subaccounts for land, timber, buildings and improvements, and Christmas trees. In many cases you'll also want to keep separate subaccounts for plantation documents (site preparation, planting, etc.), submerchantable timber, and merchantable timber, including volume data for older stands.

- Reporting your timber sale income as capital gain rather than as ordinary income can reduce taxes by avoiding the 15 percent self-employment tax. Capital gain income also has a lower marginal tax rate than ordinary income. Spread income over tax years if possible.

- Many costs of managing and maintaining your forest land are tax deductible.

- Tax credits (a direct reduction in income tax) for reforestation expenses are available for 10 percent of allowable costs. These credits, up to $\$ 10,000$ per year, are available for seedlings, planting, and other expenses including brush removal up to 2 years after planting.

- Tax deductions (reducing taxable income) for reforestation expenses are available in addition to the tax credits. These deductions are spread over 7 years. 


\section{Conservation Easement FAQ, cont.}

Q. Can the landowner still sell or give the property away?

A. The landowner continues to own the property after executing an easement. Therefore, the owner can sell, give, or lease the property as before. However, all future owners are subject to the conditions of the easement.

Q. Does the public have a right of access to easement-protected property?

A. Not unless the landowner who grants the easement specifically allows it. Most easement donors do not want, and therefore do not allow, public access to their property.

Q. How long does an easement last, and who upholds it in the future?

A. To be eligible for a federal income tax deduction the easement must be "perpetual," that is, it must last forever. The property is monitored by the land trust or government agency - the easement grantee- to assure that the terms of the easement are not being violated. If the easement has been breached, steps must be taken to uphold its terms. Land trusts typically require the landowner to make a financial contribution (tax deductible) to cover the long-term management costs of enforcing the easement.

Q. Does the easement have to cover all of the landowner's property?

A. No, some easements cover only a portion of the property; it depends on the landowner's wishes. For example, if someone owns 80 acres, of which 35 acres are wetlands, the landowner may decide to restrict development only on these 35 acres. The remaining 45 acres would not be affected by the easement.

Q. What kind of land can be protected by conservation easements?

A. IRS regulations require that the property have "significant" conservation values. This includes forests, wetlands, endangered species habitat, scenic areas, and so on.
- Generally, you'll want to expense costs (deduct them in the year they occur), depreciate what cannot be expensed, and add to the basis what cannot be expensed or depreciated, to reduce the capital gain.

- Losses from disasters such as fires or windstorms are deductible as a casualty loss.

- Cost-share payments must be reported as income, though you may be able to ultimately exclude some or all of those payments.

- Remain an active participant in your business.

- Demonstrate a profit motive in your forest property ownership by having a written long-term management plan. This helps demonstrate your profit motive so that the IRS will not consider your activity a hobby.

- Whether you manage for timber production or not it is extremely important to protect your estate. You may also want to consider the benefits of entering into conservation easements as a way of reducing tax burdens and ensuring that your management style is carried forward.

\section{RESOURCES}

\section{General Information on Taxation}

Haney, H. L. Jr, W. L. Hoover, W. C. Siegel, and J. L. Greene. 2001. Forest landowner's guide to the federal income tax. Agriculture Handbook 718. Washington, DC: Government Printing Office. USDA Forest Service Web site, http://www.srs.fs.usda.gov/pubs/misc/ah_718.pdf.

National Timber Tax Web site, http://www.timbertax.org/, an excellent source of current tax law and information.

Tax Tips for Forest Landowners, a two-page summary produced each year by the Forest Service. A free copy of the most recent summary is available from the Forest Stewardship Helpline at 1-800-738-8733. For the 2006 summary, see the Forest Service Web site, http://www.na.fs.fed.us/pubs/taxtips/taxtips.pdf.

\section{Property Taxes}

Contact your county assessor. 


\section{Yield Taxes}

California State Board of Equalization, Timber Tax Division, 450 N Street, MIC: 60, P.O. Box 942879, Sacramento, CA 94279-0060. Phone 916-445-6964 or 1-800-400-7115, Web site http://www.boe.ca.gov/.

California Timber Yield Tax. 2007. Publication 86. Sacramento: California State Board of Equalization. BOE Web site, http://www.boe.ca.gov/proptaxes/pdf/ pub86.pdf.

Guide to the California Timber Yield Tax. 2007. Publication 87. Sacramento: California State Board of Equalization. BOE Web site, http://www.boe.ca.gov/ proptaxes/pdf/pub87.pdf.

\section{Forestry-related Taxes and Estate Planning}

Haney, H. L. Jr., and W. C. Siegel. 1993. Estate planning for forest landowners: What will become of your timberland? USDA Forest Service General Technical Report SO-97. Forest Service Web site, http://soforext.net/pdfs/estate.pdf.

Hoover, W. L. Timber tax management for tree farmers. Annually updated looseleaf binder. West Lafayette, IN: Purdue University Department of Forestry and Natural Resources. For information on ordering, telephone 1-888-398-4636.

\section{ENGLISH-METRIC CONVERSIONS}

\begin{tabular}{|l|l|l|l|}
\hline English & $\begin{array}{l}\text { Conversion factor for } \\
\text { English to Metric }\end{array}$ & $\begin{array}{l}\text { Conversion factor for } \\
\text { Metric to English }\end{array}$ & Metric \\
\hline foot (ft) & 0.3048 & 3.28 & meter (m) \\
\hline yard (yd) & 0.914 & 1.09 & meter (m) \\
\hline mile (mi) & 1.61 & 0.62 & kilometer (km) \\
\hline acre (ac) & 0.4047 & 2.47 & hectare (ha) \\
\hline
\end{tabular}

\section{FOR FURTHER INFORMATION}

To order or obtain printed ANR publications and other products, visit the ANR Communication Services online catalog at http://anrcatalog.ucdavis.edu. You can also place orders by mail, phone, or FAX, or request a printed catalog of our products from:

University of California

Agriculture and Natural Resources

Communication Services

6701 San Pablo Avenue, 2nd Floor

Oakland, California 94608-1239

Telephone: (800) 994-8849 or (510) 642-2431

FAX: (510) 643-5470

E-mail inquiries: danrcs@ucdavis.edu

An electronic version of this publication is available on the ANR Communication Services Web site at http://anrcatalog.ucdavis.edu.

Publication 8252

ISBN-13: 978-1-60107-472-0

(C) 2007 by the Regents of the University of California, Division of Agriculture and Natural Resources. All rights reserved. 
The University of California prohibits discrimination or harassment of any person on the basis of race, color, national origin, religion, sex, gender identity, pregnancy (including childbirth, and medical conditions related to pregnancy or childbirth), physical or mental disability, medical condition (cancer-related or genetic characteristics), ancestry, marital status, age, sexual orientation, citizenship, or status as a covered veteran (covered veterans are special disabled veterans, recently separated veterans, Vietnam era veterans, or any other veterans who served on active duty during a war or in a campaign or expedition for which a campaign badge has been authorized) in any of its programs or activities. University policy is intended to be consistent with the provisions of applicable State and Federal laws.

Inquiries regarding the University's nondiscrimination policies may be directed to the Affirmative Action/Staff Personnel Services Director, University of California, Agriculture and Natural Resources, 300 Lakeside Drive, 6th Floor, Oakland, CA 94612-3550 (510) 987-0096. For a free catalog of other publications, call (800) 994-8849. For help downloading this publication, call (530) 297-4445.

This publication has been anonymously peer reviewed for technical accuracy by University of California scientists and other qualified professionals. This review process was managed by the ANR Associate Editor for Natural Resources.

pr-12/07-SB/RW 